\title{
SUMPIL SILAGE (Faunus ater) AS HIGH PROTEIN FISH FEED ATRACTANT FOR INCREASED PRODUCTIVITY OF FISHERIES
}

\author{
Riswi Haryatfrehni*, Rahadyan Aulia, Ihlas, Cahyo A.Wibowo, Woro Anindito S.T. \\ Faculty of Biology, Universitas Gadjah Mada \\ *Email: freeyore@gmail.com
}

\begin{abstract}
The increase in fish feed demands caused extra fee. Hence it needs to be done diversification of fish feed. Silage are food additives which function as attractants to increase appetite. Sumpil (Faunus ater) are abundance mangrove pests that contain protein. This study aims to utilize sumpil silage as fish food attractant and increase its protein content. Silage was made by mixing sumpil meat and acid of sauerkraut. Silage was incubated for $0,4,7$, and 11 days and then measured levels of protein with Lowry-Folin method. The highest levels were found in silage of 7 days incubation, which is $153.99 \mathrm{mg} / \mathrm{mL}$. The highest protein level silage mixed with the fish feed. Red tilapia maintained for 3 weeks and was given five treatments and three replications, namely feed $A$ (high protein), feed B (protein medium), feed B+silage 1\%, feed B+3\% silage, and feed $B+$ silage $5 \%$. The parameters observed were body weight and body length after feed treatment. The results showed that the average weight of fish treatmented by feed B+silage $1 \%$ and $3 \%$ are greater than the treatment of feed $B$ only but not greater than the treatment of feed $A$, although the difference was not significant. While the average length of fish relatively the same. On the other hand most rapid response was found in fish treated with feed B+silage $5 \%$. Based on the results, sumpil silage are potential as attractant that could increase fish productivity.
\end{abstract}

Keywords: Silage, sumpil, feed, attractants, protein

\section{INTRODUCTION}

Necessity of fish feed in Indonesia is increasing as well as development of fisheries sector. Based on estimation by observers, necessity of fish feed for fish and shrimp is $25 \%$ upper than other animal livestock. Therefore it is important to consider the development of processing fish feed and alternative products in Indonesia to help the fish farmers. One of the alternative products that can be developed is to use silage of sumpil (river snails) that could be made by simple technology.

Silage is produced from material that has been chemically acidified or fermented by lactic acid bacteria. Silage is one fermentation product that can serve to increase appetite, probiotics, and protein content in fish feed (Rakhmawati, 1999). Sumpil and snail are proved to have a relatively high protein content so that it can be used as an alternative food for the fulfillment of the protein elements in our body. On the other hand sumpil also considered as pest in mangrove areas which eating the new shoots grow mangroves. For that reasons control the amount of sumpil population is needed.

\section{MATERIALS AND METHODS}

Instruments are used in this study were glasswares, vortex, blender, strainer, centrifuges, spectrophotometers, buckets, scales, container, and millimeter blocks. Materials used were distilled water, starch, salt, cabbage, sumpil (Faunus ater), $\mathrm{pH}$ universal indicator, LowryFolin reagent, BSA standard solution, red tilapia fish, high protein fish feed (feed A), and 
moderate protein feed (B feed).

Sauerkraut is made by 200 grams of cabbage that has been washed then cut into pieces to get out the liquid. Salt is added $2.5 \%$ of the total weight of cabbage. Cabbages were putted in clean and covered containers. Cabbage became acid in day 6 fermentation then $\mathrm{pH}$ was measured. The success of making sauerkraut is shown with a $\mathrm{pH}$ range of 3-4. Two hundred and fifty gram sumpil were washed and added $100 \mathrm{ml}$ of distilled water and then mashed in a blender. Then added as much as 50 grams of tapioca dissolved in $100 \mathrm{ml}$ of distilled water and 37.5 grams of salt. Sauerkraut water as much $25 \mathrm{ml}$ are added into sumpil meat mixture. Then the $\mathrm{pH}$ was measured and stored in anaerobic condition. Fluid samples were taken on days $0,4,7,11$ and measured $\mathrm{pH}$.

Samples were taken then centrifuged with a speed of $3000 \mathrm{rpm}$ for $5 \mathrm{~min}$. As much as $0.2 \mathrm{ml}$ of the supernatant was diluted with $9.8 \mathrm{ml}$ of distilled water. $1 \mathrm{ml}$ was taken as a sample to be tested. The sample were added $1 \mathrm{ml}$ of Lowry A, B, and C. Homogenized solution and allowed to stand for 45 minutes. Then added $3 \mathrm{ml}$ of Folin-Ciocalteau reagent and allowed to stand for 15 minutes until the color changes. After it was measured with a spectrophotometer at a wavelength of $590 \mathrm{~nm}$ for each sample. Then made a standard curve and protein content of each sample was calculated. Silage has the highest protein content were mixed with low protein fish feed (Feed B) with a concentration of $1 \%, 3 \%$, and $5 \%$. Red tilapia aged 3 weeks (size $2-3 \mathrm{~cm}$ ) maintained at $30 \mathrm{~L}$ sized bucket, each bucket containing 15 fish. Tilapia were given 5 kinds of treatment and each treatment has 3 replications. At first bucket fed with feed $A$ (high protein fish feed, $40 \%$ ) as a positive control, the second bucket are given feed silage $B+1 \%$, the third bucket fed silage $B+3 \%$, the fourth bucket fed silage $B+5 \%$, and fifth bucket fed $B$ alone as a negative control. These samples were daily feeded by $10 \%$ of the total mass of total fish per bucket at morning and afternoon. This condition were carried out for 1.5 months and body weight and length of fish were monitored every 5 days. Bucket cleaning was done once every three days. The measurement results were then analyzed by DMRT.

\section{RESULTS AND DISCUSSION}

The principle of making silage is simplifiying protein form in a material that is more simple and soluble in water. In a food, higher soluble protein can then be absorbed by the body more efficiently (Jay et al., 2005). Another main function of silage is used as an attractant because of its fatty acid content. In this study, lactic acid is traditionally obtained by making sauerkraut. Sumpil silage incubated with variations $0,4,7$, and 11 days under anaerobic conditions. During that time, meat sumpil mixed with acid of sauerkraut. After that, the protein content was measured by Lowry-Folin method (Plummer, 1987). Protein content was measured with a wavelength of $590 \mathrm{~nm}$. Here is the result of the protein concentration by Lowry-Folin method:

The highest protein content is obtained from silage that's been incubated for 7 days amount of $153.99 \mathrm{mg} / \mathrm{mL}$. In addition, the proximate test sumpil in LPPT UGM give result that sumpil containing protein $16.39 \%, 67.23 \%$ water, $4.1 \%$ ash, $6.06 \%$ fat, $0.93 \%$ carbohydrate, and fiber $5,29 \%$. 
Table 1. Protein content of sumpil silage by Lowry-Folin method

\begin{tabular}{ccccc}
\hline \multirow{2}{*}{$\begin{array}{c}\text { Day of } \\
\text { incubation }\end{array}$} & \multicolumn{3}{c}{ Protein content $(\mathrm{mg} / \mathrm{mL})$} & $\begin{array}{c}\text { Average of } \\
\text { protein content } \\
(\mathrm{mg} / \mathrm{mL})\end{array}$ \\
\cline { 2 - 4 } & 1 & 2 & 3 & 75,55 \\
0 & 75,36 & 80,22 & 71,07 & 66,58 \\
4 & 96,67 & 30,13 & 72,93 & 153,99 \\
7 & 197,61 & 161,35 & 103,03 & 105,83 \\
\hline 11 & 94,24 & 75,93 & 147,33 & \\
\hline
\end{tabular}

Silage that has been incubated for 7 days and then tested in animal trials using red tilapia aged 3 weeks (measuring 2-3 cm). Fish at this period is in a rapid growth phase so easily observed. Tilapia are maintained for 5 weeks and given 5 kinds of treatment with each treatment has 3 replications. Fish reared in the laboratory scale in size $30 \mathrm{~L}$ bucket, each bucket containing 25 fish. Feed A has 40\% protein content worth Rp 12.000/kg while feed $B$ has a protein content of $26 \%$ worth Rp $7000.00 / \mathrm{kg}$. Making silage needs simple and inexpensive materials that can improve the protein quality of feed medium at an affordable price.

Testing is done by feeding as much as $1 \%$ of the total mass of fish in each bucket twice a day (morning and afternoon). The most rapid response of fish that is feeded by feed plus $5 \%$ silage. The parameters used to measure productivity in this study are weight and body length. Here are he result:

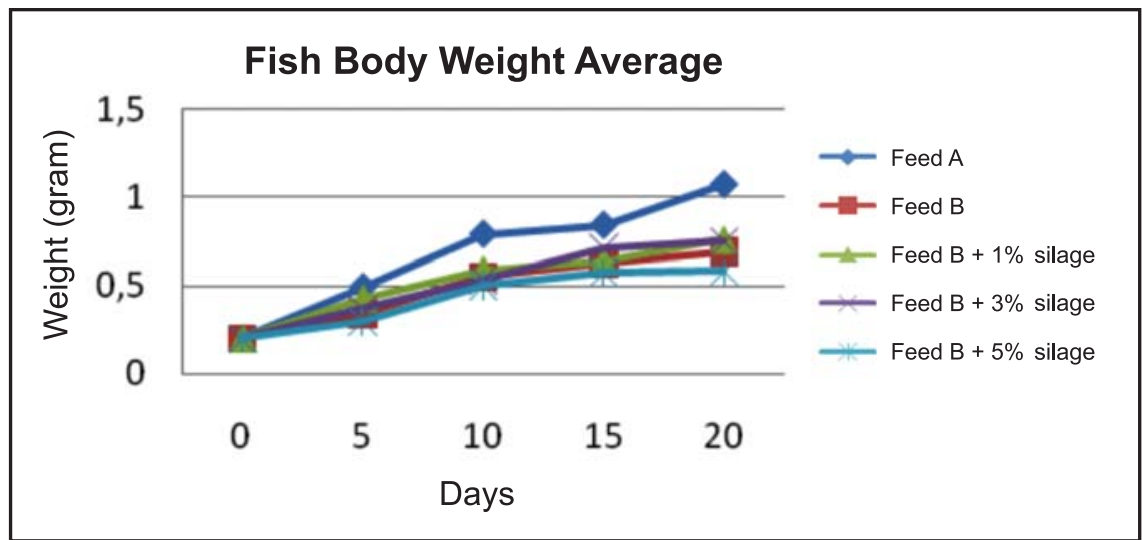

Figure 1. Comparation of Body Weight among treatments

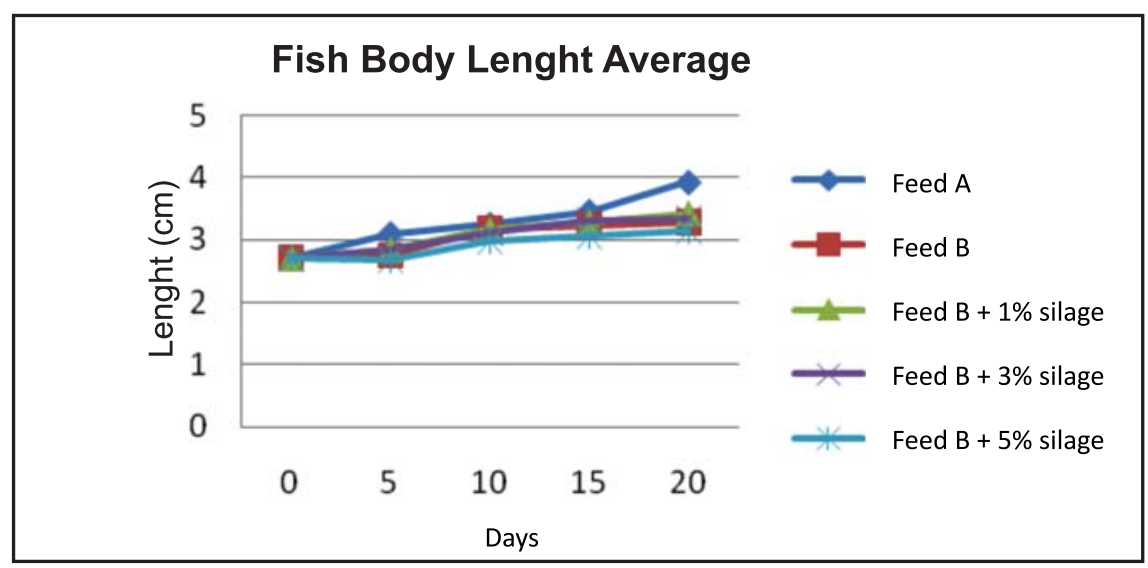

Figure 2. Comparation of Body Length among treatments 
Based on the Figure 1 and 2, the weight of fish treated feed $A$ (high protein) had a mean weight greater than others. While the $B$ feed treated silage mixed $1 \%$ and $3 \%$, the mean weight is greater than feed $B$ mixed silage $5 \%$ and feed $B$ only despite the differences between them are not significant after tested by DMRT. It can be concluded that sumpil silage has potentiality as feed atractant and increased the protein content of fish feed.

\section{ACKNOWLEDGEMENT}

Thanks to DIKTI which provides grants so that this research can be done as well to Mr. Didit and Mr. Trijoko for the suggestions.

\section{REFERENCES}

Jay, J.M.M., Martin J.L., and A.G. David. 2005. Modern Food Microbiology. $7^{\text {th }}$ ed Springer e-book USA.

Plummer, D.T. 1987. An Introduction to Practical Biochemistry $3^{\text {rd }}$ edition. Mc Graw Hill Book Company. London.

Rakhmawati, A. 1999. Pengaruh Penambahan Garam dan Tepung Tapioka Terhadap Aktivitas Bakteri Asam Laktat Pada Fermentasi Silase Limbah Ikan. Skripsi Fakultas Biologi. Universitas Gadjah Mada. Yogyakarta. 